\title{
Financial Globalization: Economic Implications for Nigeria
}

\author{
Awoyemi, Bosede Olanike, Jabar, Adebola Abass \\ ${ }^{I}$ Department of Economics Afe Babalola University, Ado Ekiti (ABUAD) \\ ${ }^{2}$ Department of Accounting Afe Babalola University, Ado Ekiti (ABUAD)
}

\begin{abstract}
The main focus of this study is to examine the economic implications of financial globalization on the Nigerian economy. This was done using the domestic savings channel and the transfer of technology channel which greatly influence economic growth in Nigeria, and the study concludes thatthe Nigeria financial system is still being gradually integrated into this globalization process. Stricter regulation, improved policy implementation, efficient risk management and systemic risk mitigation on the part of the regulators to enhance investors' confidence and ensure financial stability areneeded to ensure that the benefits of the current evolution of the financial market is sustained.
\end{abstract}

Key word: Savings, Output, Technology and Financial globalization

\section{Introduction}

The flow of foreign goods and services, direct investment as well as foreign capital and commercial operations between domestic and international markets, including entrepreneurial activities is broadly known as financial globalization. It is the integrating of a country's local financial system with international financial markets and institutions. Financial globalization integrates the world financial markets and this integration entails uniformity in the terms and conditions for raising international loans across national boundaries. The potentials of emerging market's financial systems are fully explored through integration with the rest of the world. The financial system has been identified as the mainstay of an economy. It is purported to be the transmission mechanism for behavior of various macroeconomic variables thereby propelling national economic growth. Financial globalization which represents increasing global linkages created through cross- border financial flows (Prasad, Rogoff, Wei, and Kose, 2003), is characterized with capital flows from industrial economy to developing ones. Capital inflows have thus been associated with high growth rates in some developing countries, though with attending macroeconomic costs. This is evidenced by higher profit on flow of capital from rich(developed) countries into poor (developing) countries while the flow of capital between rich (developed) countries produces lower returns. Labour is cheaper in poor countries, thus capital will have higher potential profits than flow of capital from the rich to rich countries (Mishkin, 2005). Nigeria being an emerging economy is also participatory to financial globalization.

\section{Financial globalization and Nigerian Financial System}

Nigeria's financialsystem is made up of the money and capital (debt \& equity) markets. The money market is where short-term and liquid (or near-liquid) financial instruments are created, sourced and traded with the Central Bank of Nigeria (CBN) - the apex regulatory body. The capital market, on the other hand, is involved in the mobilisation of long-term financial instruments; and is structured into the debt and equity markets. In line with two of the reform pillars of the CBN to develop the Nigerian financial markets and ensure financial system stability based on the regulator's Vision 2020 Strategy, there has been an incremental broadening of tradable and investible financial instruments backed by policy guidelines and regulations to mitigate the inherent risks involved across the money, foreign exchange, debt and capital markets.

The deepening of the Nigerian financial market is expected to play a key role in the decision making strategies of foreign portfolio investors in considering Nigeria as a viable platform to retain their capital in the medium to long term. International Monetary Fund (IMF) forecast of African Economic Growth in the World Economic Outlook's (WEO)June edition, projects five-year GDP growth for Nigeria between the periods of 2013 to 2018 to be $7.05 \%$. CBN's first quarter 2013 economic report estimated that the country's GDP grew by $6.72 \%$. This is indicative that Nigeria's financial markets, is gradually emerging in a bid to becoming a global, organised, liquid and diversified financial hub in the region of West Africa and the African continent as there is growth in the demand of financial services within the economy due to deregulation and privatization, the introduction of new technologies and new products and the entry of new competitors. 


\section{Financial globalization as a tool for Capital flow}

Flow of capital through the financial systemscannot be downplayed in the running of any economy, because it is the driving force in the wheel of the economy. It is essential to ensure an appropriate structure of capital flow into an economic system to meet the required needs of the economy per time. In other words, financial flow must match the nature of the required structure of development, otherwise, the economy will operate inefficiently and there will be low economic growth. Hence, Financial development is linked with economic growth; while financial deepening promotes financial development as it promotes the creation of private credits, which aids the creation of new firms and the development of existing industries for improved productivity in and around local financial markets and globally reduces the problem of financial information asymmetry that faces the poor countries financial systems and hence economic growth. Financial development promotes financial globalizationthrough inflow of private capital, internalization of financial services which is the increased presence of international financial intermediaries, mainly foreign banks in the domestic financial marketsand the development initiatives and supports of multilateral financial institutions. The main agents driving financial globalization are governments, private investors,local financial institutions, foreign banks, bilateral financial institutions and the development strategies of multilateral financial institutions, borrowers both for local transactions and international trade.

\section{Financial globalization and its benefits for economic growth}

Schmukler and Zoido-Lobatón (2001) discusses the opportunities and challenges that financial globalization entail for developing countries. He noted that financial globalization can lead to large benefits, particularly the development of the financial system. The study concluded that the net effect of financial globalization is likely to be positive in the long run, with risks being more prevalent immediately after countries liberalize. As the financial systems turn global, there is an increasing need, and potential, for certain forms of international financial policy cooperation among various governments.Its benefits allow healthy competitive environment which brings necessary institutional reforms such as accounting standards and disclosure requirements, extension of facilities for trade and industrial growth.These will go a long way to help domestic firms make profitable loans, borrowers taking advantage of foreign financial supports and international aids. These activities promote financial inclusion and encourages cross border economic transactions, which make the financial system work better and in turn yield increase in the size of financial sectoractivities globally, fostering economic growth.

Financial globalization increasescompetitions among the domestic firms and foreign firms in order to stimulate domestic firms to be more productive and efficient.It also increases funds available to increase liquidity and lowerthe cost of capitals thereby stimulates investment and economic growth. Financial globalization is hypothetically helpful to a country to the extent that capital inflows augment available domestic savings for investment purposes. This may be impossible where a globalized country finds itself experiencing more capital outflows than inflows. (Adegbite and Adetiloye, 2013;Schmukler, 2004)also noted that financial economic globalization bares a lot of benefits to investors that it does promote for a better financial infrastructure. He further buttressed that lenders and borrowers as a result, operate in a financial system that is more "transparent, competitive, and efficient". Hence, there is more trust in the financial system. A key benefit noted in regards to financial globalization is that capital, on a global scale, is distributed in the most efficient manner.

\section{Economic risk associated with financial globalization}

Despite various considerable benefits conferred by financial globalizationof domestic financial market, it also engenders considerable risks such as lendingbooms turning into a lending crisis; this occurs when too much loans and lack of expertise in screening and monitoring borrowers results in unfulfilled obligations and the commercial hazard of taking on excessive risksincrease the losses on loans, deteriorating the balance sheet and eventually deteriorating the firm's capital. International market imperfections such as capital flow fluctuations and shocks can lead to crisis, contagionand weaknesses in institutional reformsrendering prudential regulation and supervision ineffective, This scenario generally prevent nations from successfully handling the economics of financial globalization process, from conferring its benefits on the global community, economic and financial institutions, who naturally should have benefited from global increases in financial flows.However, unless these risks are managed efficiently, they may lead to financial crisis. Minimum government intervention, restrictions on cross-country capital movement and risk management are policy options to minimize the risk associated with financial globalization. Hence, there is little evidence to support widely-cited claims that financial globalization by itself leads to deeper and more costly developing country systemic growth crises, capable of being stimulated by inadequate global financial flow, or a subjective mismanagement of the same phenomenon. 
Basically, the attending challenge of the financial risk of financial globalization is market disturbance due to factors beyond that of the domestic market.From an investor's point of view, it can be argued that globalization of financial markets aids in spreading their risk via diversification, but when a crisis does occur, no financial market or industry is shielded. Thus, the spreading of risk efforts would be dampened due to the globalization of financial markets. Obaseki concludes that Nigeria has not benefitted enough from globalization owing to over reliance on crude oil exports, low manufacturing exports and the under-development of the domestic and financial markets.

\section{Measures of financial globalization in Nigeria Economy}

Adegbite and Adetiloye (2013) identified the factors that determine the level or degree of financial globalization of a country as the nominal exchange rate, the level of financial development as captured by the level of financial deepening of the financial system and trade. Using the Capital opening index and average exchange rates measures of financial globalization, the study showed that, for Nigeria, the greater the level of financial globalization, the more Nigeria experienced capital outflows. This is an indication that the financial globalization process has increased the interest of Nigerians to acquire assets externally resulting in loss of capital. (Adegbite and Adetiloye, 2013).However, Trade is seen as the most important of all the measures of financial globalization as there would be no financial flows without the exchange of goods and services across countries. Trade is also indicative of the level of real flow interrelation between the domestic economy and the rest of the world. However, basic approaches to measuring financial globalization have been on the level of relaxation ofrestrictions and generally the relative level of financial flows, each being measured from different angles. (Adegbite and Adetiloye, 2013).

Financial deepening is perhaps the most important of the variables of financial development. The others are money supply and credit to the private sector. Adegbite (2007) is replete with the different measurements of financial globalization. Financial development is the process of becoming a financial center which can be more propelled by financial deepening and it is operationally defined as the availability of morefinancial services and products from both the bank and non-banking financial institutions which results in highercirculation of money in the financial system. The other variables adopted for the estimation of the de facto financial globalization of Nigeria are imports and exports. The two are adopted to measure the impacts in the globalization process and in the asset and liability acquisition of the Nigerian units externally. Exports are included in the asset acquisition, while imports can lead to liability acquisitions. The average exchange rateis the rate of exchange which is important in the process of foreign investment

Furthermore, the inflow of capital needs to be complemented with adequate structures and infrastructure on the ground before it can yield the expected and authorized dividends. The de jure index of financial globalization is more explicit and has been improving gradually, with the process of adjustment programs Nigeria undertook since the mid 1980s. The index has a maximum of 2.543 for completely open and floating exchange rates. Index for Nigeria moved from -1.12942 in the seventies to -0.45086 as at year 2007 and has dropped further with current practices.

Chinn and Ito (2007) index is, exchange rate and regulatory environment based and is also a measure of financial openness. From all indications, the de facto measure, which should be superior, could be illegitimate in most developing and emerging economies as is the case of Nigeria. The Uncovered Interest Parity model uses a price-based measurement rather than an asset and liability based approach adopted by Lane and Milesi-Ferretti (2008).

The capital open measure that has not been significant in some of the countries is significant in the pooled data at 0.10 . Going by these analyses. Nigeria can be said to have achieved a level of financial globalization. One can conclude that export is particularly positively impactful on capital outflows. Capital outflows have depleted available domestic resources and impacted domestic investment negatively. The paper recommends the greater need for autonomousinvestment to crowd in other investments by implementing policies that encourage investment in the economy. This situationmay not improve until there is a proactive and deliberate action from the government to improve investment, especially oninfrastructure, in the economy.

\section{Effects of financial globalization on Nigerian economy}

(Prasad,rogof,wei and kose, 2003) provide an assessment of empirical evidence onthe effects of financial globalization for developing economies using direct and indirect channels showed that from the perspective of macroeconomic stability, consumption is regarded as a better measure of well-being than output; fluctuations in consumption are therefore regarded as having a negative impact on economic welfare and new evidence presented in this study suggests that low to moderate levels of financial integration may have made some countries subject to even greater volatility of consumption relative to that of output. Thus, while there is no proof in the data that financial globalization has benefited growth; there is evidence that some countries may have experienced greater consumption volatility as a result. 


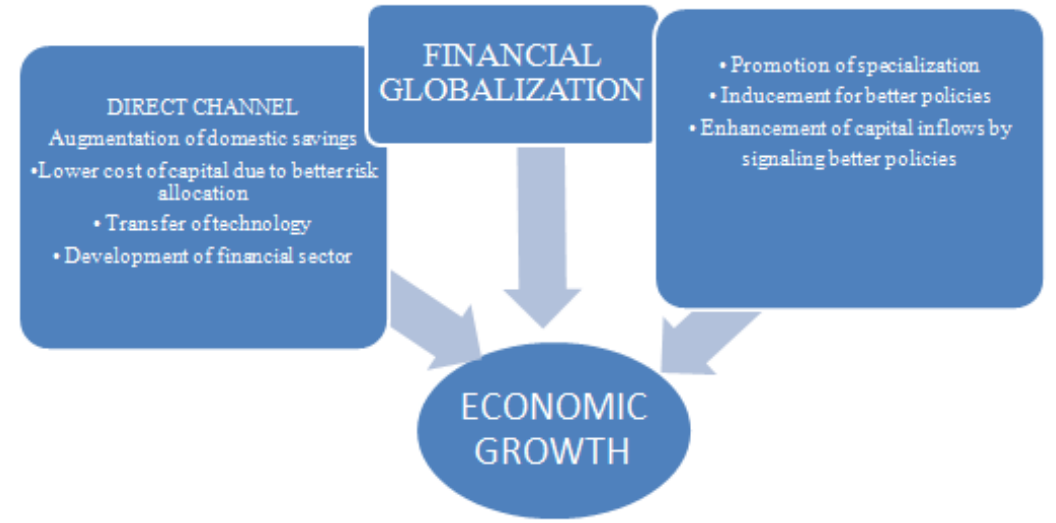

Fig. 1.1. Transmission mechanism of financial globalization (Schmukler and Zoido-Lobatón (2001))

\begin{abstract}
VIII. Methodology
Channels of financial globalization in developing countries

Financial globalization could translate to increased growth rate in developing countries through a number of channels. The channels could be direct and indirect. Direct channels are; Augmentation of domestic savings, Lower cost of capital due to better risk allocation, Transfer of Technology, and Development of finanacial sector. Indirect channels include; Promotion of specialization, Inducement for better policies, Enhancement of capital inflows by signaling better policies.
\end{abstract}

\title{
1.1. Domestic savings and economic growth in Nigeria
}

Economic theory postulate that the relationship between saving and RGDP is positive. Madison (1992), Carol and Weil (1994), and Modigliani (1970), Juster and Taylor (1975) and Jappelli and Pagano (1994) came up with the finding that saving is an increasing function of income and all had a consensus that the level of saving is influenced by the income level. The domestic Savings rate is a vital indicator or parameter of economic development as there is a positive correlation between domestic Savings rate and Investment rates. Both Savings and Investment rates are determining factors in the capacity of banks to lend to boost Output levels in the economy. Theoretical literatures reveal that the higher the level of Savings, the higher the level of investments and so the higher the Output.An empirical investigation of the causal relationship between domestic savings and economic growth, adopting Ordinary Least Square (OLS) single equation model showed a bidirectional movement from savings on real gross domestic product and real gross domestic product to savings, the study also shows the positive relationship between savings and RGDP (Nwaowi, 2010). Thus an increase in the availability of savings will lead to increase in Real Gross Domestic Product and an increase in savings will boost investment which will perhaps increase national output and in the long run encouraged national savings. Similarly, another study also investigates the interrelationship between Inflation, Savings and Output, otherwise referred to as Gross Domestic Product (GDP) in Nigeria using the VAR approach, the Granger causality test shows that showed that changes in Savings effectively stimulate Output and Output also critically cause movements in Savings in Nigeria. Thus an increase in the availability of savings will lead to increase in Real Gross Domestic Product. The relationship between domestic Savings and Output is explained from the perspective that Savings is the primary source of capital accumulation, particularly for households and entrepreneurs whose roles in an economy cannot be over-emphasized. (Igbatayo and Agbada, 2012).

\subsection{Financial globalization and technology transfer}

Transfer of technology from advanced to developing countries is one of the key channel that directly affect the determinants of economic growth. The evidence presented in this work considers a comprehensive study of the relationship between financial globalization and technology transfer in developing countries, noting the important effects of international technology transfer on the size and patterns of world trade. Peter (2002) observed that the speed at which the effect globalization is spreading is a fast day by day and no nation can afford to be behind if such a nation is to maintain an acceptable rate of growth and development. Recent development in business settings, interest in the profitable exploitation of a firm's technological assets, through technology transfer, has thus been intensified.Technology transfer is defined as the process of movement of technology from one entity to another (Souder et al. 1990; Ramanathan 1994). The transfer may be said to be successful if the receiving entity, the transfer, can effectively utilize the technology transferred and eventually assimilate it as pointed out by Ramanathan, 1994. Bozeman (2000) also corroborated this position by noting that the movement may involve physical assets, know-how, and technical knowledge Technology transfer in some situations may be confined to relocating and exchanging of personnel or the movement of a specific set of 
capabilities. Technology transfer has also been used to refer to movements of technology from the laboratory to industry, developed to developing countries, or from one application to another domain (Philips 2002). Mittleman and Pasha (1997) added that technology transfer is the movement of knowledge, skill, organization, values and capital from the point of generation of the site of adaptation and application.Empirical literatures on the technology transfer state that it is a proactive process to disseminate or acquire knowledge, experience and related artifact's (Hameri 1996, Hayami and Ruttan (1971), Mansfield (1975), Souder (1987)

Mansfield (1975) pointed out that, "One of the fundamental processes that influence the economic performance of nations and firms is technology transfer which is at the heart of the process of economic growth, and that the progress of both developed and developing countries depends on the extent and efficiency of such transfer." . He argued further that the focus is on economic growth and achievement of economic goals. However, from the perspective of business and technologists the main focus of Technology Transfer is to improve the competitive advantage of firms through the enhancement of customer value (Ramanathan, 2001). It is envisaged that, through the improvement of competitive advantage, a firm and its partners collaborating in the Technology Transfer will gain financial and other strategic benefits.

Mayer and Blaas (2002) point out that, in recent decades, SMEs have begun to utilize technology transfer as a strategic means of meeting challenges posed by the globalization of business. Due to their small size and skill resource constraints, they cannot carry out internal R\&D to generate their own technologies but still need a flow of new technology to be able to compete. This need has created a new niche-market for technology transfer (Morrissey \& Almonacid 2005). The importance of technology transfer, from an economic and competitive perspective, has also stimulated university-industry technology transfer. This is evident from the emergence of technology transfer offices in most research offices and universities (Siegel et al. 2004). Ramanathan (2000) shows that in today's international business setting, depending on the attributes of the technology, its intended use, and the motivations of the transferee and transferor, a wide range of Technology Transfer modalities are available. The focus need not merely be on the purchase of plant and equipment or licensing.

\section{Conclusion}

From the foregoing, financial globalization is arguably a broad phenomenon which represents increasing global linkages created through cross- border financial flows. Nigeria economy is an emerging economy. The potentials of emerging market's financial systems are fully explored through integration with the rest of the world. However, Nigeria financial system is still being gradually integrated into this globalization process. Stricter regulation, improved policy implementation, efficient risk management and systemic risk mitigation on the part of the regulators to enhance investors' confidence and ensure financial stability are needed to ensure that the benefits of the current evolution of the financial market is sustained.

\section{References}

[1]. Adegbite, E. Olufunmilayo and Adetiloye, K Adekunle (2013);Financial Globalization and Domestic Investment in Developing Countries: Evidence from Nigeria.

[2]. Blanchard O, (2011); Macroeconomics; 5th Edition; Englewood Cliffs; Prince Hall, Mediterranean Journal of Social Sciences, Mcser-Cemas-Sapienza University of Rome, Vol 4 No 6 July 2013

[3]. Business Day, 2013, The Evolution of the Nigerian Financial System, Business Day online,http://businessdayonline.com/2013/08/the-evolution-of-the-nigerian-financial-system/ retrieved on 27 November, 2013

[4]. Carroll, C.D., Weil, D.N., (1994);Saving and Growth: A Reinterpretation. Carnegie-Rochester Conference Series on Public Policy 40. 133-192.

[5]. G. E. Edame, 2012, Global Financial Crisis and Financial Sector Development in Nigeria, American International Journal of Contemporary Research, Vol. 2 No. 8; August 2012

[6]. Eswar Prasad, Kenneth Rogoff, Shang-Jin Wei and M. Ayhan Kose, 2003,Effects of Financial Globalization on Developing Countries: Some Empirical Evidence,International Monetary Fund, http://www.imf.org/external/pubs/nft/op/220/ retrieved on 11 November, 2013

[7]. Frederic S. Mishkin, (2005); Is Financial Globalization Beneficial?,Working Paper 11891, http://www.nber.org/papers/w11891,National Bureau of Economic Research

[8]. Maddison, A., (1992);A Long Run Perspective on Saving. Scandinavian Journal of Economics 94, $181-196$.

[9]. Modigliani, F., (1970); The Life-Cycle Hypothesis of Saving and Intercountry Differences in the Saving Ratio. In Eltis, W.A, Scott, M.F., Wolfe, J.N. (Eds.). Induction, Trade, and Growth: Essays in Honour of Sir Roy Harrod, Clarendon Press, Oxford.

[10]. Japelli T and Pagano M, (1994);Savings, Growth and Liquidity Constraints. Quarterly Journal of Economics, Vol. 109, Pg 83-109, Journal of Emerging Trends in Economics and Management Sciences (JETEMS) 3(5): 447-453,

[11]. Obaseki J. Peter, n.d.Globalisation and the Nigerian Economy, CBN Economic \& Financial Review, Vol. 38 no. 2

[12]. Pablo Zoido-Lobatón and Sergio L. Schmukler, 2013, Financial Globalization:

[13]. Opportunities and Challenges for Developing Countries.

[14]. Samuel Igbatayo and Andrew O. Agbada, (2012);Inflation, Savings and Output in Nigeria: a Var Approach

[15]. Sergio L. Schmukler (2012), The Benefits and Risks of Financial Globalization, http://www.oxfordscholarship.com/view/10.1093/acprof:oso/9780199230587.001.0001/acprof-9780199230587-chapter-2 retrieved on 11 November, 2013

[16]. Youssef Aboul-Naja, 2010,The Pros \& Cons of Financial Globalization,http://scribbledviews.wordpress.com/2010/10/10/the-proscons-of-financial-globalization/retrieved on 11 November, 2013 